\title{
The Root Cause of the Rate Performance Improvement After Metal Doping: A Case Study of $\mathrm{LiFePO}_{4}$
}

\author{
ChangKyoo Park, ${ }^{\dagger, \star}$ Sung Bin Park, ${ }^{\dagger}$ Ji Hun Park, ${ }^{\dagger,}$ Ho Chul Shin, ${ }^{\S}$ Won Il Cho, ${ }^{\ddagger}$ and Ho Jang ${ }^{\dagger, *}$ \\ ${ }^{\dagger}$ Department of Materials Science and Engineering, Korea University, Seoul 136-713, Korea. *E-mail: hojang@korea.ac.kr \\ *Advanced Battery Center, Korea Institute of Science and Technology, Seoul 136-791, Korea \\ ${ }^{\S}$ Energy Materials Lab, R\&D center, GS Caltex Corporation 104-4, Daejeon 305-380, Korea \\ Received October 25, 2010, Accepted January 11, 2011
}

\begin{abstract}
This study investigates a root cause of the improved rate performance of $\mathrm{LiFePO}_{4}$ after metal doping to $\mathrm{Fe}-$ sites. This is because the metal doped $\mathrm{LiFePO}_{4} / \mathrm{C}$ maintains its initial capacity at higher $\mathrm{C}$-rates than undoped one. Using $\mathrm{LiFePO}_{4} / \mathrm{C}$ and doped $\mathrm{LiFe}_{0.97} \mathrm{M}_{0.03} \mathrm{PO}_{4} / \mathrm{C}\left(\mathrm{M}=\mathrm{Al}^{3+}, \mathrm{Cr}^{3+}, \mathrm{Zr}^{4+}\right)$, which are synthesized by a mechanochemical process followed by one-step heat treatment, the Li content before and after chemical delithiation in the $\mathrm{LiFePO}_{4} / \mathrm{C}$ and the binding energy are compared using atomic absorption spectroscopy (AAS) and X-ray photoelectron spectroscopy (XPS). The results from AAS and XPS indicate that the low Li content of the metal doped $\mathrm{LiFePO}_{4} / \mathrm{C}$ after chemical delithiation is attributed to the low binding energy induced by weak Li-O interactions. The improved capacity retention of the doped $\mathrm{LiFePO}_{4} / \mathrm{C}$ at high discharge rates is, therefore, achieved by relatively low binding energy between $\mathrm{Li}$ and $\mathrm{O}$ ions, which leads to fast $\mathrm{Li}$ diffusivity.
\end{abstract}

Key Words : $\mathrm{LiFePO}_{4}$, Doping, Rate performance, XPS, Binding energy

\section{Introduction}

Olivine-type lithium iron phosphate $\left(\mathrm{LiFePO}_{4}\right)$ has been considered as a promising candidate for a cathode material in the lithium-ion batteries after first introduced by Goodenough's group in 1997. ${ }^{1}$ This is because $\mathrm{LiFePO}_{4}$ has the advantages of high theoretical capacity $\left(170 \mathrm{mAh} \mathrm{g}^{-1}\right)$, excellent thermal stability, and non-toxicity ${ }^{2,3}$ compared to conventional $\mathrm{LiCoO}_{2}$. However, its low electronic conductivity $\left(10^{-9} \sim 10^{-10} \mathrm{~S} \mathrm{~cm}^{-1}\right)$ and low lithium ion diffusivity lead to slow electron movement and poor $\mathrm{Li}$ ion transfer under rapid rates, impeding the rate capability. ${ }^{4-7}$ To overcome the drawbacks of $\mathrm{LiFePO}_{4}$, recent efforts have been given to the improvement of rate performance by coating carbonaceous conductors ${ }^{8-11}$ and substituting Li with metals such as $\mathrm{Nb}, \mathrm{Mg}, \mathrm{Zr}$, or $\mathrm{Cr}{ }^{12,13}$ Concerning the position of the added metals in the lattice, Fe sites have been also considered as a suitable position to enhance the rate performance of $\mathrm{LiFePO}_{4}$. Baker et al. ${ }^{14}$ incorporated $\mathrm{Mg}$ ion to $\mathrm{Fe}$ ion sites and delivered initial capacity $156 \mathrm{mAh} \mathrm{g}^{-1}$. Wang et al., on the other hand, improved initial capacity and reversibility by producing P-type semiconductor regions in a $\mathrm{LiFePO}_{4}$ particle by doping $\mathrm{Ti}$ ions. ${ }^{15}$ They ascribed the beneficial doping effects to the improvement of electronic conductivity after doping.

In this study, the binding energy and chemical compositions of $\mathrm{LiFePO}_{4} / \mathrm{C}$ and $\mathrm{LiFe}_{0.97} \mathrm{M}_{0.03} \mathrm{PO}_{4} / \mathrm{C}\left(\mathrm{M}=\mathrm{Al}^{3+}, \mathrm{Cr}^{3+}\right.$, $\mathrm{Zr}^{4+}$ ) are measured by X-ray photoelectron spectroscopy (XPS), and Atomic absorption spectroscopy (AAS) is used to examine the amount of $\mathrm{Li}$ content. The mechanism of improved rate performance is examined by comparing the binding energy, chemical composition, and Li content of the
$\mathrm{LiFePO}_{4}$ before and after doping.

\section{Experimental}

A mixture of $\mathrm{Li}_{2} \mathrm{CO}_{3}$ (Aldrich, $\geq 99 \%$ ), $\mathrm{FeC}_{2} \mathrm{O}_{4} \cdot 2 \mathrm{H}_{2} \mathrm{O}$ (Junsei, $\geq 99 \%$ ), $\left(\mathrm{NH}_{4}\right) \mathrm{H}_{2} \cdot \mathrm{PO}_{4}$ (Junsei, $\geq 99 \%$ ), and 3 wt \% of carbon black powder were placed in a zirconia bowl and the mechanochemical reaction was carried out for $3 \mathrm{hrs}$ in a planetary mill (FRITSCH Pulverisette 5). The rotation speed was $250 \mathrm{rpm}$ and the ball-to-powder weight ratio was 20:1. The resulting powder mixture was heat treated at $750{ }^{\circ} \mathrm{C}$ for 10 hours under $\mathrm{Ar}+5 \% \mathrm{H}_{2}$ atmosphere to produce carbon coated $\mathrm{LiFePO}_{4}$. The metal doped $\mathrm{LiFe}_{0.97} \mathrm{M}_{0.03} \mathrm{PO}_{4} / \mathrm{C}(\mathrm{M}=$ $\mathrm{Al}^{3+}, \mathrm{Cr}^{3+}, \mathrm{Zr}^{4+}$ ) powder was also prepared by the same procedure. The precursors such as $\mathrm{Al}\left(\mathrm{C}_{2} \mathrm{H}_{5} \mathrm{O}\right)_{3}$ (Aldrich, $\geq 97 \%$ ), $\left(\mathrm{CH}_{3} \mathrm{CO}_{2}\right)_{7} \mathrm{Cr}_{3}(\mathrm{OH})_{2}$ (Aldrich, $\geq 97 \%$ ), and $\mathrm{Zr}\left(\mathrm{OC}_{2} \mathrm{H}_{5}\right)_{4}$ (Aldrich, $\geq 97 \%$ ) were used to dope $\mathrm{Al}, \mathrm{Cr}$, and $\mathrm{Zr}$ ions, respectively. The crystal structure of $\mathrm{LiFePO}_{4}$ was analyzed by X-ray diffraction (XRD; D/MAX-II A) using $\mathrm{Cu} \mathrm{K} \mathrm{K}_{\alpha}$ radiation varying between $15^{\circ}-45^{\circ}(2 \theta)$. The morphology of the $\mathrm{LiFePO}_{4}$ was examined by a field emission scanning electron microscope (FE-SEM, Hitachi, S-4200, Japan).

The cathode was composed of active materials, acetylene black, and polyvinylidene fluoride (PVDF) at a weight ratio of 85:10:5 and was coated onto an $\mathrm{Al}$ foil. The cathode was held in a vacuum oven at $80{ }^{\circ} \mathrm{C}$ for $12 \mathrm{hrs}$. After drying it, the cathode was $60 \mu \mathrm{m}$ thick, containing approximately 5-7 $\mathrm{mg} \mathrm{cm}{ }^{-2}$ of the active materials. $1 \mathrm{M} \mathrm{LiPF}_{6}$ in an ethylene carbonate/dimethyl carbonate/ethylmethyl carbonate (EC/ $\mathrm{DMC} / \mathrm{EMC}$ ) solution and lithium foil were used as electrolyte and the counter electrode, respectively. A standard coin cell (2032 type) was used to examine the charging and 
discharging activities of the cathode. The Maccor 4000 battery cycler with cut-off voltages in the range of 2.5-4.3 V was used to analyze the rate performance at various $\mathrm{C}$ rates. The samples were discharged five cycles at $0.2,0.5,1,2,5$, $10,15,20,25$, and $30 \mathrm{C}$, respectively, and charged at $0.2 \mathrm{C}$ for an accurate comparison of the electrochemical properties. Cyclic voltammetry $(\mathrm{CV})$ was carried out at scan voltage range from 2.8 to $4.2 \mathrm{~V}$ at $0.01 \mathrm{mV} \mathrm{s}^{-1}$. Chemical delithiation of $\mathrm{LiFePO}_{4}$ was carried out by mixing $\mathrm{LiFePO}_{4}$ with $\mathrm{K}_{2} \mathrm{~S}_{2} \mathrm{O}_{8}$ at the ratio of $4: 1{ }^{16}$ The mixture of $\mathrm{LiFePO}_{4}$ and $\mathrm{K}_{2} \mathrm{~S}_{2} \mathrm{O}_{8}$ was dissolved in water and stirred at room temperature for $24 \mathrm{~h}$. After filtered and dried at $800{ }^{\circ} \mathrm{C}$, the composition of the powder was obtained by inductively
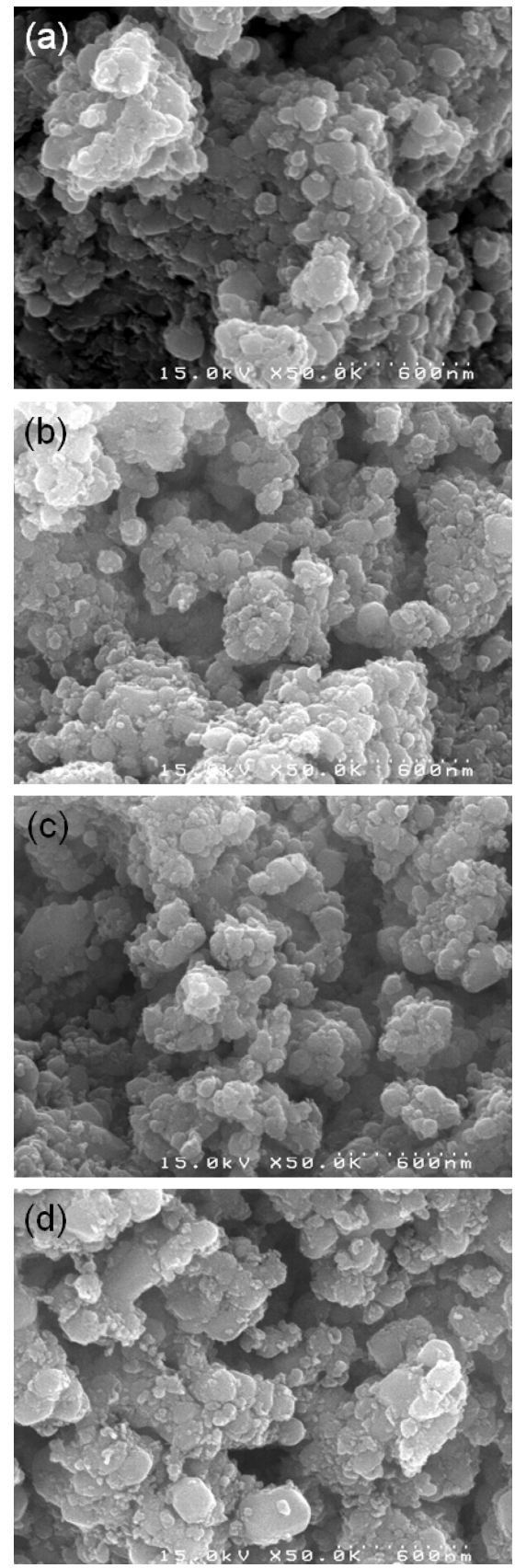

Figure 1. SEM micrographs of (a) $\mathrm{LiFePO}_{4} / \mathrm{C}$, (b) $\mathrm{LiFe}_{0.97} \mathrm{Al}_{0.03}$ $\mathrm{PO}_{4} / \mathrm{C}$, (c) $\mathrm{LiFe}_{0.97} \mathrm{Cr}_{0.03} \mathrm{PO}_{4} / \mathrm{C}$, and (d) $\mathrm{LiFe}_{0.97} \mathrm{Zr}_{0.03} \mathrm{PO}_{4} / \mathrm{C}$. coupled plasma (ICP, POLYSCAN-61E) except Li and Fe, which were analyzed by Atomic absorption spectroscopy (AAS, SOLAAR M) to compare Li content before and after chemical delithiation. To examine the binding energy and chemical composition of the $\mathrm{LiFePO}_{4}, \mathrm{X}$-ray photoelectron spectroscopy (XPS, PHI 5000 VersaProbe, Ulvac-PHI) was used.

\section{Results and Discussion}

The particle morphology of the sample was examined first since the particle size determines the diffusion distance through the particle and effective surface area for the electrochemical reaction. Figure 1 shows the SEM images of the undoped and metal doped $\mathrm{LiFe}_{0.97} \mathrm{M}_{0.03} \mathrm{PO}_{4} / \mathrm{C} \quad\left(\mathrm{M}=\mathrm{Al}^{3+}\right.$, $\left.\mathrm{Cr}^{3+}, \mathrm{Zr}^{4+}\right)$. They showed similar fine particles in the size range of 100-200 $\mathrm{nm}$. The small adherents on the surface of $\mathrm{LiFePO}_{4}$ particles appeared to be carbon black. This carbon layer restrains particle growth during heat-treatment and improved electrochemical properties by decreasing the $\mathrm{Li}$ ion diffusion path. ${ }^{17}$

The structure of the $\mathrm{LiFePO}_{4} / \mathrm{C}$ and $\mathrm{LiFe}_{0.97} \mathrm{M}_{0.03} \mathrm{PO}_{4} / \mathrm{C}$ $(\mathrm{M}=\mathrm{Al}, \mathrm{Cr}, \mathrm{Zr}$ ) was investigated by XRD (Fig. 2). XRD profiles showed pure phases with an ordered olivine structure and the secondary phases such as $\mathrm{Fe}_{2} \mathrm{p}$ and $\mathrm{Li}_{3} \mathrm{PO}_{4}$ were not detected. The lattice parameter obtained from the samples showed slightly changed (Table 1), which indicated that $\mathrm{Fe}$ ion might be substituted by $\mathrm{M}$ ion $(\mathrm{M}=\mathrm{Al}, \mathrm{Cr}, \mathrm{Zr})$. Figure 3 shows three different XRD peaks from $(101),(111) /(201)$, and $(211) /(202)$ planes of $\mathrm{LiFePO}_{4} / \mathrm{C}, \mathrm{LiFe}_{0.97} \mathrm{Al}_{0.03} \mathrm{PO}_{4} / \mathrm{C}$, $\mathrm{LiFe}_{0.97} \mathrm{Cr}_{0.03} \mathrm{PO}_{4} / \mathrm{C}$, and $\mathrm{LiFe}_{0.97} \mathrm{Zr}_{0.03} \mathrm{PO}_{4} / \mathrm{C}$. The figures clearly illustrate the peak shift from $0.04^{\circ}$ to $0.14^{\circ}$ after metal doping, which lead to change the lattice parameter. This result substantiates the doped ion such as $\mathrm{Al}, \mathrm{Cr}$ and $\mathrm{Zr}$ ion replace Fe ion.

The CV profiles of $\mathrm{LiFePO}_{4} / \mathrm{C}$ and $\mathrm{LiFe}_{0.97} \mathrm{M}_{0.03} \mathrm{PO}_{4} / \mathrm{C}$ $\left(\mathrm{M}=\mathrm{Al}^{3+}, \mathrm{Cr}^{3+}, \mathrm{Zr}^{4+}\right)$ were obtained at a scan rate of 0.01 $\mathrm{mVs}^{-1}$ during the redox reaction and shown in Figure 4.

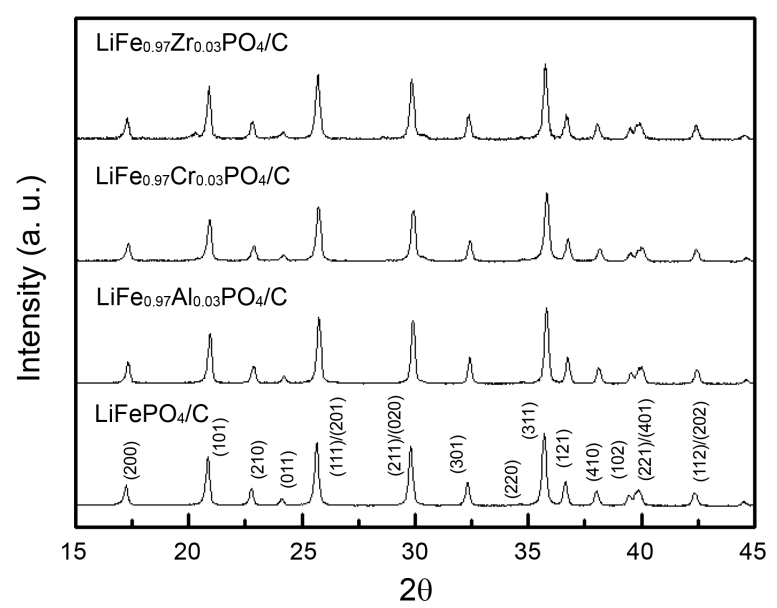

Figure 2. $\mathrm{XRD}$ profiles of $\mathrm{LiFePO}_{4} / \mathrm{C}, \mathrm{LiFe}_{0.97} \mathrm{Al}_{0.03} \mathrm{PO}_{4} / \mathrm{C}$, $\mathrm{LiFe}_{0.97} \mathrm{Cr}_{0.03} \mathrm{PO}_{4} / \mathrm{C}$ and $\mathrm{LiFe}_{0.97} \mathrm{Zr}_{0.03} \mathrm{PO}_{4} / \mathrm{C}$ were heat-treated at $750{ }^{\circ} \mathrm{C}$ for $10 \mathrm{~h}$. 
Table 1. The lattice parameters of $\mathrm{LiFePO}_{4} / \mathrm{C}$ and doped $\mathrm{LiFePO}_{4} /$ $\mathrm{C}$

\begin{tabular}{lcccc}
\hline & $a(\AA)$ & $b(\AA)$ & $c(\AA)$ & $V\left(\AA^{3}\right)$ \\
\hline $\mathrm{LiFePO}_{4} / \mathrm{C}$ & 10.2867 & 6.0021 & 4.6825 & 289.1057 \\
$\mathrm{LiFe}_{0.97} \mathrm{Al}_{0.03} \mathrm{PO}_{4} / \mathrm{C}$ & 10.2547 & 5.9846 & 4.6684 & 286.4985 \\
$\mathrm{LiFe}_{0.97} \mathrm{Cr}_{0.03} \mathrm{PO}_{4} / \mathrm{C}$ & 10.2488 & 5.9676 & 4.6747 & 285.9074 \\
$\mathrm{LiFe}_{0.97} \mathrm{Zr}_{0.03} \mathrm{PO}_{4} / \mathrm{C}$ & 10.2729 & 5.9989 & 4.6782 & 288.2948 \\
\hline
\end{tabular}
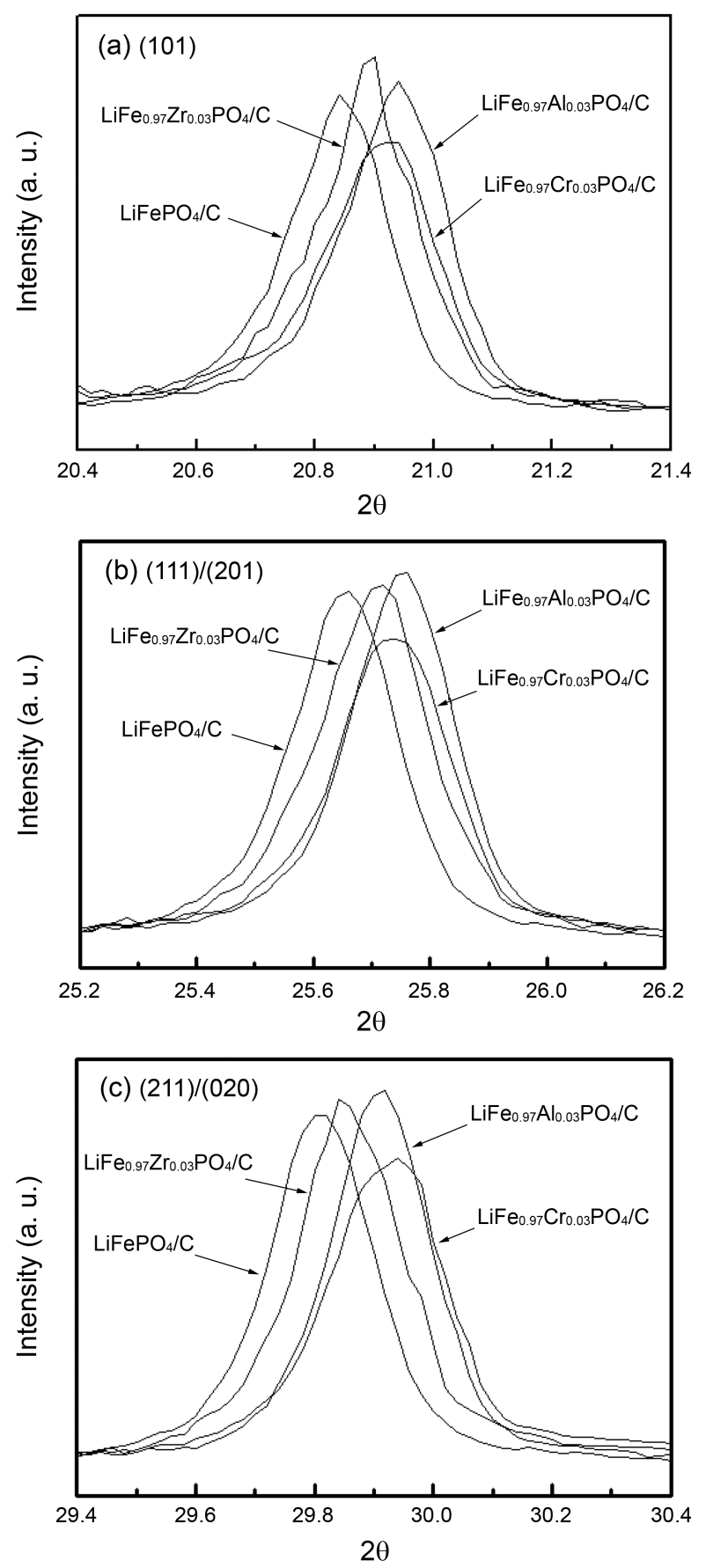

Figure 3. XRD peak profiles of $\mathrm{LiFePO}_{4} / \mathrm{C}$ and doped $\mathrm{LiFe}_{0.97}-$ $\mathrm{M}_{0.03} \mathrm{PO}_{4} / \mathrm{C}$ in plane (a) (101), (b) (111)/(201), and (c) (211)/(020).

Distinct anodic (charge) and cathodic (discharge) peaks were found from the samples indicating a redox reaction in a

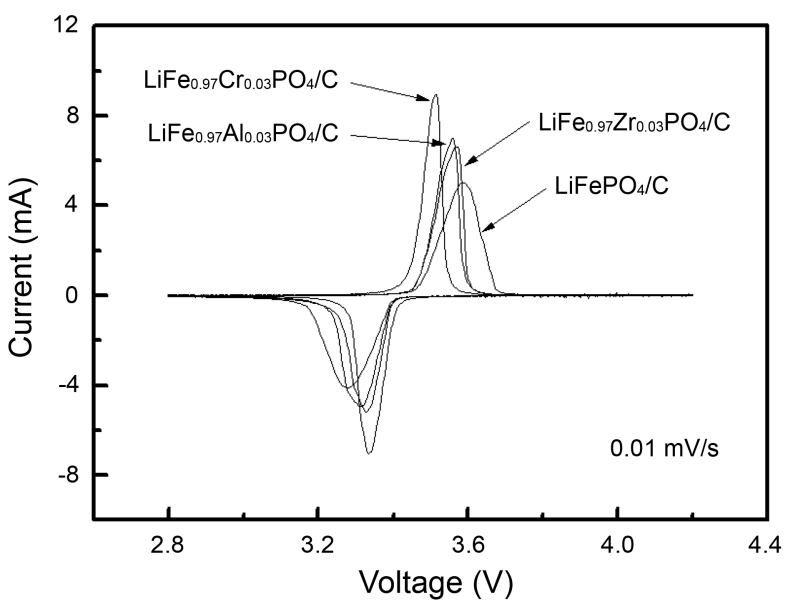

Figure 4. $\mathrm{CV}$ profiles of $\mathrm{LiFePO}_{4} / \mathrm{C}$ and doped $\mathrm{LiFePO}_{4} / \mathrm{C}$ at a scan rate of $0.01 \mathrm{mVs}^{-1}$.
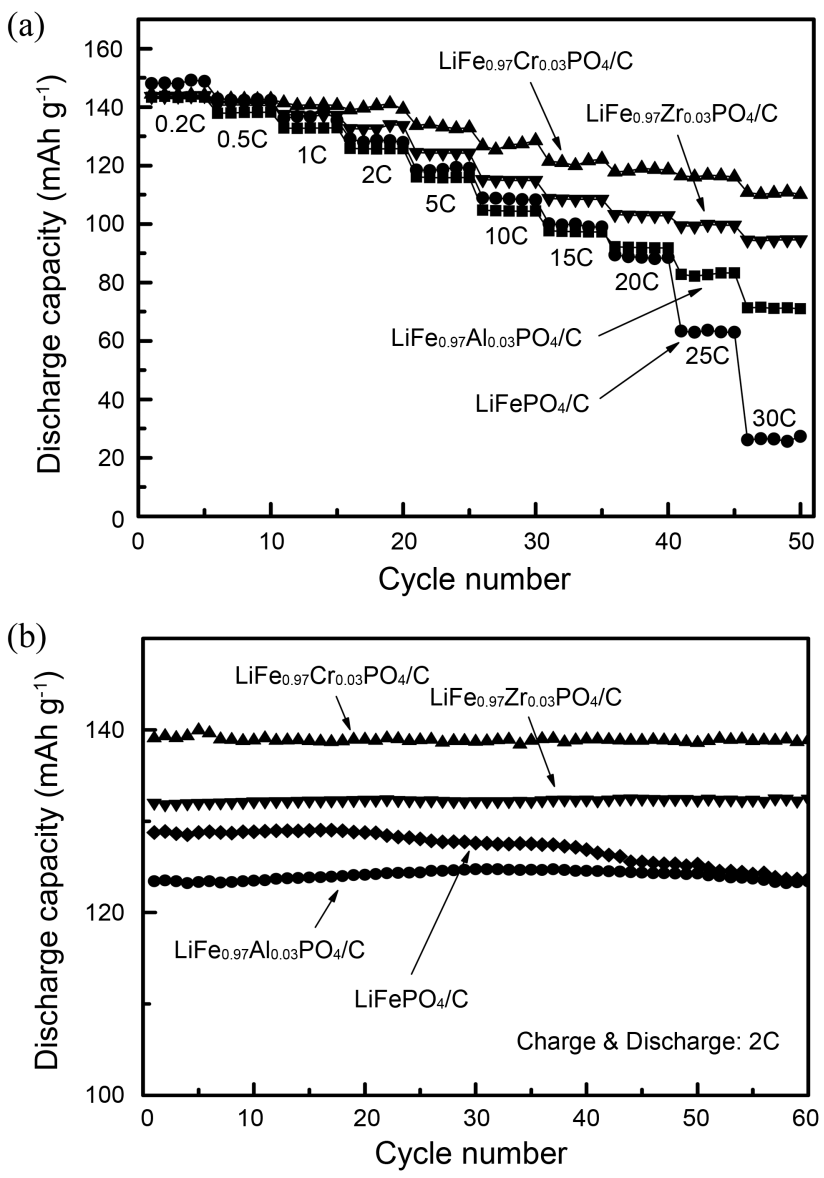

Figure 5. (a) Rate performance at various $\mathrm{C}$ rates and (b) cycleability at $2 \mathrm{C}$ rate of $\mathrm{LiFePO}_{4} / \mathrm{C}, \mathrm{LiFe}_{0.97} \mathrm{Al}_{0.03} \mathrm{PO}_{4} / \mathrm{C}, \mathrm{LiFe}_{0.97} \mathrm{Cr}_{0.03}-$ $\mathrm{PO}_{4} / \mathrm{C}$ and $\mathrm{LiFe}_{0.97} \mathrm{Zr}_{0.03} \mathrm{PO}_{4} / \mathrm{C}$.

two phase system. However, the shape and intensity of the current peaks were changed considerably after doping. The doped $\mathrm{LiFePO}_{4} / \mathrm{C}$ cathodes exhibited narrower peaks than undoped $\mathrm{LiFePO}_{4} / \mathrm{C}$, which suggested that the metal ion incorporation facilitated $\mathrm{Li}$ ion diffusion during the redox reaction. In addition, $\mathrm{LiFe}_{0.97} \mathrm{M}_{0.03} \mathrm{PO}_{4} / \mathrm{C}\left(\mathrm{M}=\mathrm{Al}^{3+}, \mathrm{Cr}^{3+}, \mathrm{Zr}^{4+}\right)$ 
showed the reduced peak separation between the cathodic and anodic peaks which indicated that metal doping weakens the polarization. Shin et al. ${ }^{18}$ reported a similar result with the narrow current peaks after Cr doping, which was attributed to the decreased polarization resistance of the cathode.

The rate performance of $\mathrm{LiFePO}_{4} / \mathrm{C}$ and doped $\mathrm{LiFePO}_{4} /$ $\mathrm{C}$ were compared at discharge rates from $0.2 \mathrm{C}$ to $30 \mathrm{C}$ and shown in Figure 5 (a). The initial capacity of the $\mathrm{LiFePO}_{4} / \mathrm{C}$ was $147.9 \mathrm{mAh} \mathrm{g}^{-1}$ at $0.2 \mathrm{C}$. On the other hand, the doped $\mathrm{LiFePO}_{4} / \mathrm{C}$ showed slightly lower initial capacity of $143.3 \mathrm{mAh} \mathrm{g}^{-1}, 144.4 \mathrm{mAh} \mathrm{g}^{-1}$, and $143.7 \mathrm{mAh} \mathrm{g}^{-1}$, from $\mathrm{LiFe}_{0.97} \mathrm{Al}_{0.03} \mathrm{PO}_{4} / \mathrm{C}, \mathrm{LiFe}_{0.97} \mathrm{Cr}_{0.03} \mathrm{PO}_{4} / \mathrm{C}$, and $\mathrm{LiFe}_{0.97} \mathrm{Zr}_{0.03} \mathrm{PO}_{4} / \mathrm{C}$, respectively. However, as the discharge current density increased, $\mathrm{LiFePO}_{4} / \mathrm{C}$ showed severe capacity reduction down to $26.2 \mathrm{mAh} \mathrm{g}^{-1}$ at $30 \mathrm{C}$. On the other hand, $\mathrm{LiFe}_{0.97} \mathrm{M}_{0.03} \mathrm{PO}_{4} / \mathrm{C}\left(\mathrm{M}=\mathrm{Al}^{3+}, \mathrm{Cr}^{3+}, \mathrm{Zr}^{4+}\right)$ exhibited excellent capacity retention at high $\mathrm{C}$-rates. Even at $30 \mathrm{C}$, the capacities of $\mathrm{LiFe}_{0.97} \mathrm{Al}_{0.03} \mathrm{PO}_{4} / \mathrm{C}, \mathrm{LiFe}_{0.97} \mathrm{Cr}_{0.03} \mathrm{PO}_{4} / \mathrm{C}$, and $\mathrm{LiFe}_{0.97} \mathrm{Zr}_{0.03} \mathrm{PO}_{4} / \mathrm{C}$ were maintained at $71.3 \mathrm{mAh} \mathrm{g}^{-1}, 110.8$ $\mathrm{mAh} \mathrm{g}^{-1}$, and $94.5 \mathrm{mAh} \mathrm{g}^{-1}$, respectively. The doped $\mathrm{LiFePO}_{4} /$ $\mathrm{C}$, in general, exhibited excellent rate capability and $\mathrm{LiFe}_{0.97} \mathrm{Cr}_{0.03} \mathrm{PO}_{4} / \mathrm{C}$ was found to have the best performance. Figure 5 (b) showed the cycleability of $\mathrm{LiFePO}_{4} / \mathrm{C}$ and doped $\mathrm{LiFePO}_{4} / \mathrm{C}$ at $2 \mathrm{C}$ charge-discharge rate. The doped $\mathrm{LiFePO}_{4} / \mathrm{C}$ maintained their initial capacity, while $\mathrm{LiFePO}_{4} /$ $\mathrm{C}$ showed capacity reduction after 60 cycles. These results demonstrate the positive role of metal doping for the fade resistance of $\mathrm{LiFePO}_{4}$, which leads to the improvement of the electrochemical performance at high $\mathrm{C}$ rates. The improvement of the rate performance by metal doping has been observed by others and they explained the performance improvement by enhanced electronic conductivity. ${ }^{12-15}$

To find the root cause of the improvement of rate performance after metal doping, chemical delithiation of the $\mathrm{LiFePO}_{4}$ was conducted by atomic absorption spectroscopy (AAS) and inductively coupled plasma (ICP). Table 2 shows the initial compositions of the four different samples before chemical delithiation. The $\mathrm{Li}$ content of $\mathrm{LiFePO}_{4} / \mathrm{C}$ was 1 mol, while the doped $\mathrm{LiFePO}_{4} / \mathrm{C}$ contained $\mathrm{Li}$ content from 0.98 to $0.99 \mathrm{~mol}$. The deficiency of the Li ion in the doped
$\mathrm{LiFePO}_{4} / \mathrm{C}$ is attributed to the charge compensation after doping $\mathrm{Al}^{3+}, \mathrm{Cr}^{3+}$, and $\mathrm{Zr}^{4+}$ ions instead of $\mathrm{Fe}^{2+}$ ion, ${ }^{19}$ causing the slight drop of initial capacity at $0.2 \mathrm{C}$, as shown in Figure 5. Table 3 represents the composition of the samples after chemical delithiation. It shows that $\mathrm{LiFe}_{0.97} \mathrm{Al}_{0.03} \mathrm{PO}_{4} / \mathrm{C}$, $\mathrm{LiFe}_{0.97} \mathrm{Cr}_{0.03} \mathrm{PO}_{4} / \mathrm{C}$, and $\mathrm{LiFe}_{0.97} \mathrm{Zr}_{0.03} \mathrm{PO}_{4} / \mathrm{C}$ contain 0.57 , 0.55 , and $0.56 \mathrm{~mol}$ of $\mathrm{Li}$, respectively, so that $0.42,0.43$, and $0.43 \mathrm{~mol}$ of $\mathrm{Li}$ ion escape from the particle. On the other hand, $0.66 \mathrm{~mol}$ of $\mathrm{Li}$ remains in the undoped $\mathrm{LiFePO}_{4} / \mathrm{C}$, indicating that more $\mathrm{Li}$ ions are extracted from the doped $\mathrm{LiFePO}_{4} / \mathrm{C}$ than $\mathrm{LiFePO}_{4} / \mathrm{C}$ during chemical delithiation. This result suggests that the doped $\mathrm{LiFePO}_{4} / \mathrm{C}$ has a weaker binding force between $\mathrm{Li}$ and other surrounding elements than that of $\mathrm{LiFePO}_{4} / \mathrm{C}$. It facilitates the $\mathrm{Li}$ ion diffusion so that the Li ion can escape the particle easily. The result of elemental composition is well coincided with the rate performance. In other words, the metal doped $\mathrm{LiFePO}_{4} / \mathrm{C}$, which contained a smaller amount of $\mathrm{Li}$ content after chemical delithiation demonstrated excellent capacity retention, while undoped $\mathrm{LiFePO}_{4} / \mathrm{C}$ showed sharp capacity fading.

In order to understand the experimental result from chemical delithiation, the chemical binding energy of the

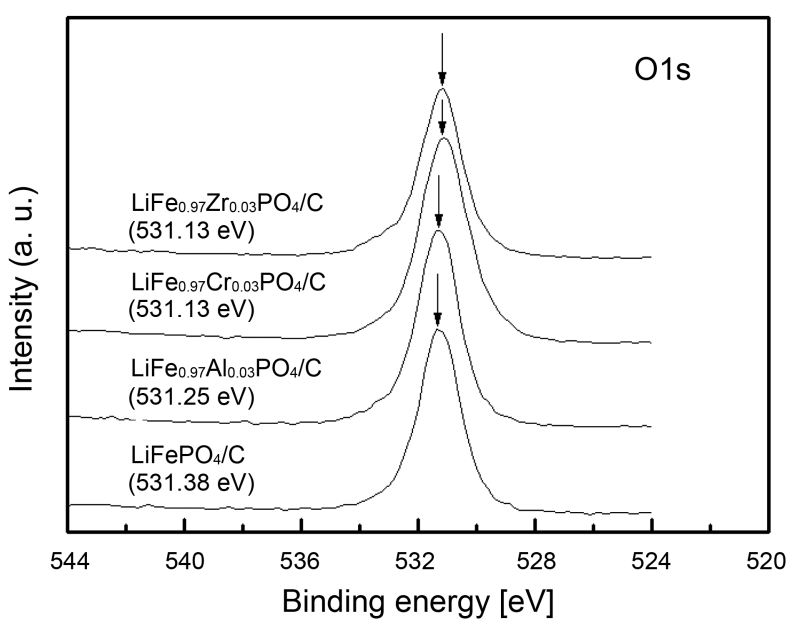

Figure 6. Peaks of chemical binding energy from XPS analysis of bare $\mathrm{LiFePO}_{4} / \mathrm{C}$ and $\mathrm{LiFe}_{0.97} \mathrm{M}_{0.03} \mathrm{PO}_{4} / \mathrm{C}\left(\mathrm{M}=\mathrm{Al}^{3+}, \mathrm{Cr}^{3+}, \mathrm{Zr}^{4+}\right)$.

Table 2. Elemental composition of the samples before chemical delithiation

\begin{tabular}{lcccccc}
\hline & $\mathrm{Li}(w t \%)$ & $\mathrm{Fe}($ wt \%) & $\mathrm{M}($ wt \%) & $\mathrm{P}($ wt \%) & $\mathrm{C}($ wt \%) & $\mathrm{Li}: \mathrm{Fe}: \mathrm{M}: \mathrm{P}(\mathrm{P}=1)$ \\
\hline $\mathrm{LiFePO} / \mathrm{C}$ & 3.93 & 32.0 & - & 17.5 & 2.97 & $1.00: 1.01: 1$ \\
$\mathrm{LiFe}_{0.97} \mathrm{Al}_{0.03} \mathrm{PO}_{4} / \mathrm{C}$ & 3.78 & 30.5 & 0.47 & 17.1 & 2.89 & $0.99: 0.99: 0.03: 1$ \\
$\mathrm{LiFe}_{0.97} \mathrm{Cr}_{0.03} \mathrm{PO}_{4} / \mathrm{C}$ & 3.72 & 30.1 & 0.85 & 16.9 & 2.95 & $0.98: 0.99: 0.03: 1$ \\
$\mathrm{LiFe}_{0.97} \mathrm{Zr}_{0.03} \mathrm{PO}_{4} / \mathrm{C}$ & 3.61 & 29.3 & 1.43 & 16.2 & 3.01 & $0.99: 1.00: 0.03: 1$ \\
\hline
\end{tabular}

Table 3. Elemental composition of the samples after chemical delithiation

\begin{tabular}{lcccccl}
\hline & $\mathrm{Li}(\mathrm{wt} \%)$ & $\mathrm{Fe}(\mathrm{wt} \%)$ & $\mathrm{M}(\mathrm{wt} \%)$ & $\mathrm{P}(\mathrm{wt} \%)$ & $\mathrm{C}($ wt \%) & $\mathrm{Li}: \mathrm{Fe}: \mathrm{M}: \mathrm{P}(\mathrm{P}=1)$ \\
\hline $\mathrm{LiFePO}_{4} / \mathrm{C}$ & 2.91 & 35.7 & - & 19.7 & 2.95 & $0.66: 1.01: 1$ \\
$\mathrm{LiFe}_{0.97} \mathrm{Al}_{0.03} \mathrm{PO}_{4} / \mathrm{C}$ & 2.40 & 34.3 & 0.50 & 18.9 & 2.91 & $0.57: 1.01: 0.03: 1$ \\
$\mathrm{LiFe}_{0.97} \mathrm{Cr}_{0.03} \mathrm{PO}_{4} / \mathrm{C}$ & 2.36 & 34.8 & 0.99 & 19.2 & 2.97 & $0.55: 1.01: 0.03: 1$ \\
$\mathrm{LiFe}_{0.97} \mathrm{Zr}_{0.03} \mathrm{PO}_{4} / \mathrm{C}$ & 2.35 & 33.9 & 1.50 & 18.6 & 2.98 & $0.56: 1.01: 0.03: 1$ \\
\hline
\end{tabular}



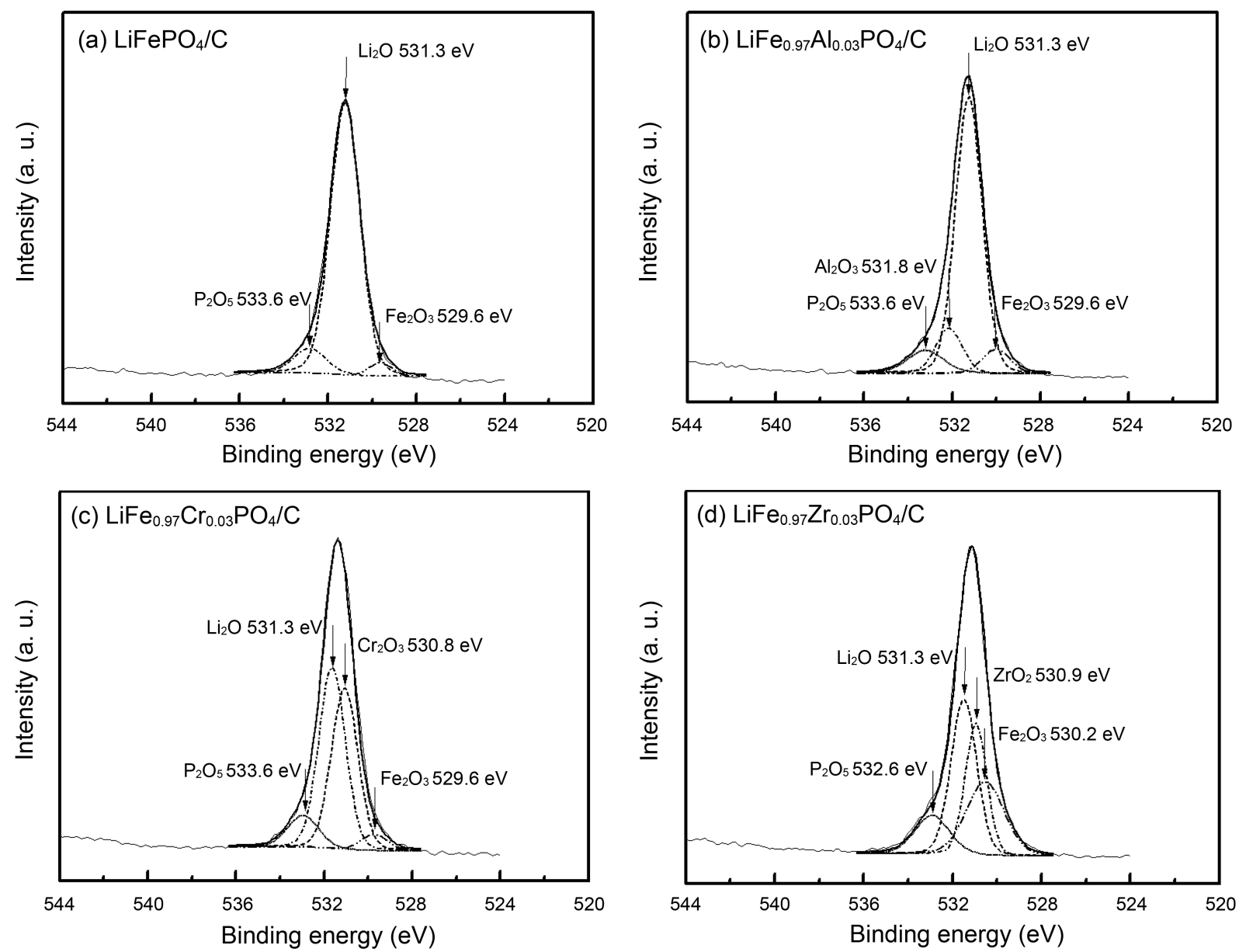

Figure 7. XPS depth profile of O1s peaks: (a) $\mathrm{LiFePO}_{4} / \mathrm{C}$, (b) $\mathrm{LiFe}_{0.97} \mathrm{Al}_{0.03} \mathrm{PO}_{4} / \mathrm{C}$, (c) $\mathrm{LiFe}_{0.97} \mathrm{Cr}_{0.03} \mathrm{PO}_{4} / \mathrm{C}$, and (d) $\mathrm{LiFe}_{0.97} \mathrm{Zr}_{0.03} \mathrm{PO}_{4} / \mathrm{C}^{23}$

samples were measured by X-ray photoelectron spectroscopy (XPS). Figure 6 shows the O1s peaks obtained from four different samples which describes the chemical environment between $\mathrm{Li}$ and $\mathrm{O}$. The figure illustrates that the XPS peaks from doped $\mathrm{LiFePO}_{4} / \mathrm{C}$ are decreased slightly compared to undoped $\mathrm{LiFePO}_{4} / \mathrm{C}$. The binding energy of $\mathrm{LiFePO}_{4} / \mathrm{C}$ was $531.38 \mathrm{eV}$, while that of $\mathrm{LiFe}_{0.97} \mathrm{Al}_{0.03} \mathrm{PO}_{4} / \mathrm{C}$, $\mathrm{LiFe}_{0.97} \mathrm{Cr}_{0.03} \mathrm{PO}_{4} / \mathrm{C}$, and $\mathrm{LiFe}_{0.97} \mathrm{Zr}_{0.03} \mathrm{PO}_{4} / \mathrm{C}$ were $531.25 \mathrm{eV}$, $531.13 \mathrm{eV}$, and $531.13 \mathrm{eV}$, respectively. The result was well consistent with the binding energy of O1s peak obtained from Liu et al. ${ }^{20}$ and Lu et al., ${ }^{21}$ which demonstrated the binding energy of $\mathrm{O} 1 \mathrm{~s}$ peak at $531.5 \mathrm{eV}$ and $531.6 \mathrm{eV}$, respectively. Wang et al. $^{22}$ also reported a similar result showing the reduction of the $\mathrm{O} 1$ binding energy after doping metal ions to $\mathrm{LiFePO}_{4} / \mathrm{C}$.

Figure 7 shows the O1s peak profiles from four different samples. The $\mathrm{O} 1 \mathrm{~s}$ peak from $\mathrm{LiFePO}_{4} / \mathrm{C}$ consisted of three distinct peaks corresponding to $\mathrm{P}_{2} \mathrm{O}_{5}, \mathrm{Li}_{2} \mathrm{O}$, and $\mathrm{Fe}_{2} \mathrm{O}_{3}$ and the $\mathrm{Li}_{2} \mathrm{O}$ peak coincided well to the $\mathrm{O} 1 \mathrm{~s}$ peak, which indicated that $\mathrm{Li}_{2} \mathrm{O}$ was dominant in oxygen bonding. On the other hand, when the metals such as $\mathrm{Al}, \mathrm{Cr}$, and $\mathrm{Zr}$ were incorporated instead of $\mathrm{Fe}$, the $\mathrm{O} 1 \mathrm{~s}$ peaks were consisted of four different peaks. This is because new compositions were established after metal doping and the new peaks were corresponded to $\mathrm{Al}_{2} \mathrm{O}_{3}, \mathrm{Cr}_{2} \mathrm{O}_{3}$, and $\mathrm{ZrO}_{2}$. As a result, the shape and intensity of the three original peaks were altered due to newly created peaks. In the case of undoped $\mathrm{LiFePO}_{4} / \mathrm{C}$, a $\mathrm{Li}_{2} \mathrm{O}$ peak was the most dominant peak and it almost coincided with the $\mathrm{O} 1 \mathrm{~s}$ peak, indicating that $\mathrm{Li}-\mathrm{O}$ bonding maintained sufficiently strong interaction in the undoped $\mathrm{LiFePO}_{4} / \mathrm{C}$. Whereas, the $\mathrm{Li}_{2} \mathrm{O}$ peaks from the doped $\mathrm{LiFePO}_{4} / \mathrm{C}$ was decreased by metal doping and as a result, newly produced peaks corresponding to $\mathrm{Al}_{2} \mathrm{O}_{3}, \mathrm{Cr}_{2} \mathrm{O}_{3}$, and $\mathrm{ZrO}_{2}$ or already existing $\mathrm{P}_{2} \mathrm{O}_{5}$ and $\mathrm{Fe}_{2} \mathrm{O}_{3}$ peaks were increased. This suggested that $\mathrm{Li}-\mathrm{O}$ interaction was weakened by metal doping, which improved the rate performance of the doped $\mathrm{LiFePO}_{4} / \mathrm{C}$ due to high $\mathrm{Li}$ diffusion.

\section{Conclusions}

The chemical binding energy of $\mathrm{LiFePO}_{4} / \mathrm{C}$ and $\mathrm{LiFe}_{0.97} \mathrm{M}_{0.03} \mathrm{PO}_{4} / \mathrm{C}\left(\mathrm{M}=\mathrm{Al}^{3+}, \mathrm{Cr}^{3+}, \mathrm{Zr}^{4+}\right)$ was measured using XPS techniques to find the cause of the improvement in rate performance after metal doping. The position of the O1s peaks from doped $\mathrm{LiFePO}_{4} / \mathrm{C}$ was decreased in the range of 0.13 to $0.25 \mathrm{eV}$ compared to undoped $\mathrm{LiFePO}_{4} / \mathrm{C}$, and the analysis of the peak profiles of XPS demonstrated that the intensity of $\mathrm{Li}_{2} \mathrm{O}$ peak was significantly decreased after doping. The results of the elemental composition before and after chemical delithiation illustrated that approximately 
$0.43 \mathrm{~mol}$ of the $\mathrm{Li}$ content escaped from the doped $\mathrm{LiFePO}_{4} / \mathrm{C}$, while only $0.34 \mathrm{~mol}$ of $\mathrm{Li}$ content is extracted from the undoped $\mathrm{LiFePO}_{4}$. Both the results confirmed that the Li-O interaction was weakened by metal doping and it facilitated $\mathrm{Li}$ diffusion, which is the root cause of the improved rate performance of the doped $\mathrm{LiFe}_{0.97} \mathrm{M}_{0.03} \mathrm{PO}_{4} / \mathrm{C} \quad\left(\mathrm{M}=\mathrm{Al}^{3+}\right.$, $\left.\mathrm{Cr}^{3+}, \mathrm{Zr}^{4+}\right)$.

Acknowledgments. This work was supported by Energy Resource R\&D Programs (2009201010003B-11-3-020 and 2008EEL11P0800002009) under the Ministry of Knowledge Economy, Republic of Korea.

\section{References}

1. Padhi, A. K.; Nanjundaswamy, K. S.; Goodenough, J. B. J. Electrochem. Soc. 1997, 144, 1188-1194.

2. MacNeil, D. D.; Lu, Z.; Chen, Z.; Dahn, J. R. J. Power Sources 2002, 108, 8-14.

3. Takahashi, M.; Tobishima, S. I.; Takei, K.; Sakurai, Y. Solid State Ionics 2002, 148, 283-289.

4. Padhi, A. K.; Nanjundaswamy, K. S.; Masquelier, C.; Okada, S.; Goodenough, J. B. J. Electrochem. Soc. 1997, 144, 1609-1613.

5. Takahashi, M.; Tobishima, S.; Takei, K.; Sakurai, Y. J. Power Sources 2001, 97/98, 508-511.

6. Barker, J.; Saidi, M. Y.; Swoyer, J. L. Electrochem. Solid-State Lett. 2003, 6, A53-A55.

7. Andersson, A. S.; Kalska, B.; Haggstrom, L.; Thomas, J. O. Solid State Ionics 2000, 130, 41-52.
8. Ravet, N.; Chouinard, Y.; Magnan, J. F.; Besner, S.; Gauthier, M.; Armand, M. J. Power Sources 2001, 97-98, 503-507.

9. Prosini, P. P.; Zane, D.; Pasquali, M. Electrochim. Acta 2001, 46, 3517-3523.

10. Huang, H.; Yin, S. C.; Nazar, L. F. Electrochem, Solid State Lett. 2001, 4, A170-A172.

11. Chen, Z.; Dahn, J. R. J. Electrochem. Soc. 2002, 149, A1184A1189.

12. Chung, S. Y.; Bloking, J. T.; Chiang, Y. M. Nat. Mater. 2002, 1, 123-128.

13. Shi, S.; Liu, L.; Ouyang, C.; Wang, D. S.; Wang, Z.; Chen, L.; Huang, X. Phys. Rev. B 2003, 68, 195108, 1-5.

14. Baker, J.; Saidi, M. Y.; Swoyer, J. L. Electrochem. Solid-state Lett. 2003, 6, 53.

15. Wang, G. X.; Needham, S.; Yao, J. J. Power Sources 2006, 159, 282-286.

16. Ait-Salah, A.; Dodd, J.; Mauger, A.; Yazami, R. Z. Anorg. Allg. Chem. 2006, 632, 1598-1605.

17. Shin, H. C.; Cho, W. I.; Jang, H. Electrochim. Acta 2006, 52, 1472-1476.

18. Shin, H. C.; Park, S. B.; Jang, H.; Chung, K. Y.; Cho, W. I. Electrochim. Acta 2008, 53, 7946-7951.

19. Meethong, N.; Kao, Y. H.; Speakman, S. A.; Chiang, Y. M. Adv Funct. Mater. 2009, 19, 1060-1070.

20. Liu, H.; Yang, H.; Li, J. Electrochim. Acta 2010, 55, 1626-1629.

21. Lu, J.; Tang, Z.; Zhang, Z.; Shen, W. Materials Research Bulletin 2005, 40, 2039-2046.

22. Wang, D.; Li, H.; Shi, S. Electrochim. Acta 2005, 50, 2955-2958.

23. Moulder, J. F.; Stickle, W. F.; Sobol, P. E.; Bomben, K. D. Handbook of X-ray Phototelectron Spectroscopy; Physical Electronics Inc.: 1995. 